Relations industrielles

Industrial Relations

\title{
Labour Education
}

\section{The Educational Service of the C.T.C.C.}

\section{Fernand Jolicoeur}

Volume 4, numéro 6, février 1949

URI : https://id.erudit.org/iderudit/1023499ar

DOI : https://doi.org/10.7202/1023499ar

Aller au sommaire du numéro

Éditeur(s)

Département des relations industrielles de l’Université Laval

ISSN

0034-379X (imprimé)

1703-8138 (numérique)

Découvrir la revue

Citer cet article

Jolicoeur, F. (1949). Labour Education: The Educational Service of the C.T.C.C.

Relations industrielles / Industrial Relations, 4(6), 58-59.

https://doi.org/10.7202/1023499ar

Tous droits réservés @ C Département des relations industrielles de l’Université Laval, 1949
Ce document est protégé par la loi sur le droit d'auteur. L'utilisation des services d'Érudit (y compris la reproduction) est assujettie à sa politique d'utilisation que vous pouvez consulter en ligne.

https://apropos.erudit.org/fr/usagers/politique-dutilisation/ 
seems to be that the child which has grown up to be the Government, and which soon may be the largest employer in Great Britain, will use the closed shop through the Trades Union Congress to perpetuate itself and crush all opposition. » ${ }^{4}$
But this political debate does not at all affect private enterprise where the closed shop remains a practice accepted by all to the point where they do not even take the trouble to include it as a special clause in collective labour agreements.

(4) Jerome Toner, op. cit., p. 15.

LABOUR EDUCATION

\section{THE EDUCATIONAL SERVICE OF THE C.C.C.L.}

\section{FERnand Jolicoeur}

The Canadian and Catholic Confederation of Labour (La Confédération des Travailleurs Catholiques du Canada) comprises to-day close to 90,000 members. It has become a commonplace to say that it is now the most representative labour movement in the Province of Quebec. This continuous expansion is as much due to the competence and the devotion of its organizers and technicians as to the value of the principles which animate it.

Facing this accomplished fact and the unknown future a prob!em is presented for the C.C.C.L. (C.T.C.C.) that of consolidating definitely the position acquired before directing its action towards the single aim it should pursue and which can assure it life, that aim which the social doctrine of the Church points out. In order to state precisely this aim, to make it known in all the labour movement, and to train its members to seek after it «by the easiest and shortest way », the C.C.C.L. has founded its own Educational Service.

One cannot imagine a trade union movement, much less one of Christian inspiration, without an organization for instruction. Moreover, the story of the C.C.C.L. amply proves that it hat not departed from this principle. From its beginnings we meet with study groups where were trained the leaders who brought about its present stature.

At Quebec, Monsieur l'abbé Maxime Fortin, first chaplain of the C.C.C.L., organized about 1915 what he called the "Commission des Questions Ouvrières de l'Action Sociale Catholique». At Montreal, Monsieur l'abbé Edmour Hébert, with the aid of the "École Sociale Populaire», founded in 1918 the famous Leo XIII Club considered as the first union study group of the movement. In each region of the Province these examples were followed with good results and towards 1938 the \& Fédération des Cercles d'Etudes » of the C.C.C.L. was formed. This latter functioned until 1946 when they commenced to think of a more elaborate organization better suited to the new needs of the labour world.

They sought after a formula while they awaited the financial means needed to start a real educational service where a full-time employee could direct the work and guide the studies on all the necessary levels. At the C.C.C.L. Congress at Hull, in October last the long-cherished project finally took form. The Educational Service of the C.C.C.L. came into existence and an officer of the movement took charge at the beginning of November last.

To explain the nature and the rôle of this new service it must be said, first of all, that it was not a school where the instructors would dispense learning that the C.C.C.L. wished to found but rather a center for studying together. As the name well expresses it, this will be a «service 》 organized to direct, to compile and to diffuse studies, a service to which will contribute all the leaders of the movement and from which will profit all the workers.

This new union service should not content itself with the initiating into unionism, indispensable as this is, nor with the training of negotiators, but, above all should explain the profound meaning of unionism, the reason and the essential direction of the labour movement.

Now the C.C.C.L. takes its stand on the social doctrine of the Church, to affirm that the present structure of society must be radically reformed. And it believes that trade unionism is a basic element in a future society. 
The present frame-work of society does not include the working classes. It is unionism which has the mission of intregating these classes into the new limits which are being imposed, and then of teaching them the rights and the duties which derive from their new responsibilities.

It is not then simply a question of appeasing the workers' claims, still less of making use of unionism to consolidate the present position of economic society. Nor is it even a question of putting forward certain formulae which, without a force to control them, far from orientating a!l society towards the pursuit of the common wellbeing, would finish by thansforming the workers themselves into profiteers.

Pius XII, in his discourse to the Catholic Association of Italian Workers, (June 29, 1948) indicates * the lofty aim towards which should tend 》 the !abour movement - « the training of really Christian workers who, excelling equally in the capacity for their art and in religious consciousness, know to bring into harmony the firm protection of their economic interests with the strictest sentiment of justice and with the sincere determination to collaborate with the other classes of society in the Christian renewal of the whole social iife». There is all the program of the Educational Service of the C.C.C.L. On it devolves the duty of maintaining and passing on this really inspiring idea.
This organism responds to a pressing need. The Catholic and national union movement has such a need of earnest leaders, proud of their industrial organization, enlightened as much in their economic as in their social point of view, «living witnesses of a doctrine which does not err », leaders who know where they go and towards what heights unionism should be directed!

The Educational Service of the C.C.C.L. will make it a duty to co-operate with all those who are occupied with labour training, and with adult education. It will need the experience of everybody to attain this end. To-day, it exists itself because it hastens to train more militant syndicalists «who accept only the principles of justice and Christian charity which cost them something 》 according to the phrase of the general secretary of the C.C.C.L., Monsieur Jean Marchand.

Unionism is an element of reform, not of revolt, or of more first-aid for the present economic society. It tends to collaboration with those who compose it. There is the problem as it shou!d be stated. One must be of the movement, not to understand it, but to feel it, not to explain it, but to realize it even while explaining it. That is the reason why the C.C.C.L. determined to inaugurate its own Educationa! Service which will set forth this prob!em and participate in its solution.

\section{A READER'S COMMENTS}

\section{The future of the Collective Agreement Act}

It is always of importance to défine precisely principles and facts. In the field of labour relations the interralationships between these two terms are ordinarily specified and put in concrete form by laws - general or sociological laws and special or codified laws. These general laws become codified only when they have first of all been confirmed by habits or social facts.

The situation in labour relations prior to 1934 was largely elemental. No legislation, or more exactly, an uncertain legislation regulated activities in the field. When the law was adopted it was evident that its principal aim was to popularize the collective agreements with juridical extension. Definite facts had lead to the promulgation of some such measure.

The Legislator had taken into account first of all that competition amongst similar industries constituted the principal obstacle to the spread of collective labour agreements. Faced with union agreement the employer would give voice to the following opinion: «You cannot require me, a particular employer, to submit myself to conditions from which my principal competitor is exempted. Have this agreement signed by all $m y$ competitors at the same time and I will myself accept the collective agreement which you submit to me, thus we will all be on the same footing of equality. 》

To summarize the affair - being given that wages are a constituent element of the cost price, the employer has but to increase his selling price proportionately in order to receive an equivalent value. But to be obliged to increase a cost price when a competitor can leave his at the previous level is to be placed in an inferior competitive position.

The Collective Agreement Act aims at surmounting this obstacle by decreeing the extention of some of the clauses of the collective agreement to similar branches of economic activity on condition that the stipulations have, in the opinion of the Labour Minister, « a preponderant significance and importance.»

An interesting article appearing in the December issue of the \&ulletin des relations industrielles $\gg$ of Laval includes, in my opinion, a too-generalized eulogy of the Collective Agreement Act. Not that the eulogy is not intrinsically earned but that the author seems to want to make of the said law a universal panacea for all the ills inherent in labour relations. We might well bring into consideration the sociological limitations of such a law :

1) The union agreement is the basis of the collective agreement with juridical extension. 